\title{
Beneficial effects of methanolic extract of Indigofera linnaei Ali. on the inflammatory and nociceptive responses in rodent models
}

\author{
Raju Senthil Kumar ${ }^{1, *}$, Balasubramanian Rajkapoor ${ }^{2}$, Perumal Perumal $^{3}$, Sekar Vinoth Kumar', \\ Arunachalam Suba Geetha ${ }^{1}$
}

\author{
${ }^{1}$ Natural Products Laboratory, Swamy Vivekanandha College of Pharmacy, Tiruchengodu, Tamilnadu, India, ${ }^{2}$ Department \\ of Pharmacology, Faulty of Medicine, Sebha University, Sebha, Libya, ${ }^{3}$ Department of Pharmaceutical Chemistry, Nirmala \\ College of Pharmacy, Kizhakkekara, Muvattupuzha, Kerala, India
}

\begin{abstract}
Indigofera linnaei Ali. (Tamil Name: Cheppu Nerinjil) belongs to the family Fabaceae, used for the treatment of various ailments in the traditional system of medicine. In the present study, the beneficial effects of methanol extract of whole plant of I. linnaei (MEIL) were evaluated on inflammation and nociception responses in rodent models. In vitro nitric oxide (NO), lipoxygenase (LOX) and cyclooxygense (COX) inhibitory activities were also performed to understand the mode of action. MEIL at the dose of $200 \& 400 \mathrm{mg} / \mathrm{kg}$, p.o. significantly inhibited carrageenan induced rat paw volume and reduced the weight of granuloma in cotton pellet granuloma model. The results obtained were comparable with the standard drug aceclofenac. The anti-nociceptive effect of MEIL in mice was evaluated in hot plate and acetic acid induced writhing model. The plant extract significantly reduced the number of writhes and the analgesic effect was higher than that of the standard drug aspirin. However, the extract fails to increase the latency period in hot plate method suggesting that the extract produce nociception by peripheral activity. The extract produced inhibitory effect on NO, LOX and COX in concentration dependent manner. The extract exhibited pronounced and selective COX-2 inhibition. Altogether, these results suggested that the methanol extract of Indigofera linnaei could be considered as a potential antiinflammatory and analgesic agent.
\end{abstract}

Uniterms: IIndigofera linnaei/pharmacognosy. Indigofera linnaei/anti-inflammatory activity. Indigofera linnaei/analgesic activity. Indigofera linnaei/anti-nociceptive effect. Nitric oxide/scavengers. Cyclooxygenase/inhibitors. Lipoxygenase/inhibitors. Medicinal plants.

Indigofera linnaei Ali pertence à família Leguminosae e é utilizada para o tratamento de várias doenças na medicina tradicional. No presente estudo, os efeitos benéficos do extrato metanólico da planta inteira de I. linnaei (MEIL) foram avaliados em respostas inflamatórias e nocicepção em modelos de roedores. Testes in vitro de atividade inibitória do óxido nítrico (NO), lipoxigenase (LOX) e ciclooxigenase (COX) também foram realizados para compreender o modo de ação. MEIL nas doses de 200 e $400 \mathrm{mg} / \mathrm{kg}$, p.o. inibiu significativamente o volume da pata de rato induzido por carragenana e reduziu o peso do granuloma no modelo de pélete de algodão. Os resultados obtidos foram comparáveis ao do fármaco padrão, aceclofenaco. O efeito anti-nociceptivo de MEIL foi avaliado em camundongos no modelo de placa quente e de contorção induzida por ácido acético. O extrato da planta reduziu significativamente o número de contorções e o efeito analgésico foi maior do que o do fármaco padrão, ácido acetilsalicílico. Porém, o extrato não conseguiu aumentar o período de latência no método da placa quente, sugerindo que este produz nocicepção por atividade periférica. $O$ extrato produziu efeito inibitório sobre o NO, LOX e COX dependente da concentração. O extrato exibiu inibição acentuada e seletiva da COX-2. No seu conjunto, estes resultados sugerem que o extrato metanólico de Indigofera linnaei poderia ser considerado como agente anti-inflamatório e analgésico potencial.

Unitermos: Indigofera linnaei/farmacognosia. Indigofera linnaei/atividade anti-inflamatória. Indigofera linnaei/atividade analgésica. Indigofera linnaei/efeito anti-nociceptivo. Óxido nítrico/sequestrantes. Lipoxigenase/inibidores. Ciclooxigenase/inibidores. Plantas medicinais.

*Correspondence: Raju Senthil Kumar. Natural Products Laboratory. Swamy Vivekanandha College of Pharmacy, Elayampalayam Post, Tiruchengodu 637 205, Tamilnadu, India. E-mail: thrisen@gmail.com. 


\section{INTRODUCTION}

Inflammation is a protective response of the body towards various injurious stimuli like infections and trauma (Vijayalakshmi et al., 2011; Yonathan et al., 2006). At the same time it is accompanied with pain, redness, swelling and malfunctioning of the affected part of the body (Amira et al., 2012). Inflammatory process involves the release of various chemical mediators that are responsible for signs and symptoms associated with such conditions. Prostaglandins are ubiquitous substances that indicate and modulate cell and tissue responses involved in inflammation. Their biosynthesis has also been implicated in the pathophysiology of cardiovascular diseases, cancer, colonic adenomas and Alzheimer's disease. To alleviate the pain and other associated symptoms various anti-inflammatory agents are used, most of which are synthetic drugs, associated with various side effects such as peptic ulcer, bleeding etc. (Dharmasiri et al., 2003; Bepary et al., 2008). Based on ethnopharmacological uses, many medicinal plants have attracted considerable interest, particularly in the treatment of various disease conditions including chronic inflammatory diseases (Moro et al., 2012). The research into medicinal plants with alleged folkloric use as analgesics, anti-inflammatory agents, should therefore be viewed as a fruitful and logical research strategy in the search for new analgesic and antiinflammatory drugs.

Indigofera linnaei Ali (Syn: Indigofera enneaphylla L.) belongs to the family Fabaceae and is a reputed indigenous medicine. It is a small trailing, much branched annual or biennial herb, distributed throughout India. The juice of the plant is used as antiscorbutic and diuretic, for burns and epilepsy. It has long been used by the ethnic people and native medical practitioners to treat rheumatism, arthritis, inflammation, tumor and liver diseases (Wealth..., 1992). Literature review reveal that three nitropropanoyl esters of glucose namely 1,2,6-tri-O-(3-nitropropanoyl)- $\beta$-D-glucopyranose, 2,3,4,6-tetra-O-(3-nitropropanoyl)- $\alpha$-D-glucopyranose and 3,4,6-tri- $O$-(3-nitropropanoyl)- $\alpha$-D-glucopyranose were isolated from the aerial parts of Indigofera linnaei (Majak et al., 1992). The plant exhibit wound healing activity in rats (Hemalatha et al., 2001). A new isoflavone namely 7,8-methylenedioxy-4'-methoxyisoflavone has been isolated from the entire plant of Indigofera linnaei (Rajendraprasad, Chakradhar, 2004). In our earlier studies, the plant extract exhibited a potent free radical scavenging and antioxidant activity (Kumar et al., 2011a) and anticancer activity (Kumar et al., 2011b). In continuation of our previous works on this plant, the present study was aimed to evaluate the beneficial effects of methanol extract of Indigofera linnaei (MEIL) on inflammatory and nociceptive responses in rodent models.

\section{MATERIAL AND METHODS}

\section{Chemicals}

Kappa carrageenan type III, acetylsalicylic acid, linoleic acid, lipoxygenase (lipoxidase from soyabean), Dulbecco's Modified Eagle's Medium (DMEM), fetal bovine serum (FBS), penicillin, streptomycin, naphthylethylenediamine dihydrochloride, LPS were purchased from Sigma Chemicals Co., (St. Louis, USA). Pentazocin was obtained from Ranbaxy Laboratories Ltd. (New Delhi, India). Aceclofenac was obtained from Micro Labs (Hosur, India). All other chemical used were of analytical grade. Murine monocytic macrophage cell line RAW 264.7 was procured from National Centre of Cell Science (Pune, India).

\section{Plant material and Extraction}

Entire plants of I. linnaei were collected from the foothills of Yercaud in the month of November 2014. The plant was authenticated by Dr. G.V.S. Murthy, Joint Director, Botanical Survey of India, Coimbatore, Tamilnadu, India. A voucher specimen is preserved in our laboratory for future reference (Voucher No. P. Ch. IL 002). The plant material was shade dried, pulverized and extracted $(500 \mathrm{~g})$ by cold maceration process with $80 \%$ methanol at room temperature for $72 \mathrm{~h}$. The extract was filtered and concentrated to dryness under reduced pressure and controlled temperature $\left(40{ }^{\circ} \mathrm{C}\right.$ to $\left.50^{\circ} \mathrm{C}\right)$ in a rotary evaporator. The extract was a dark yellowish brown solid weighing $50.2 \mathrm{~g}$ (yield, $10.4 \%$ ) and was preserved in a vacuum desiccator until further use.

\section{Animals}

Male Wistar albino rats (150-200 g) and Swiss albino mice (20-25 g) were procured from Venkatershwara Enterprises, Bangalore, Karnataka, India, and used throughout the study. The animals were housed in microlon boxes in a controlled environment (temperature $25 \pm 2{ }^{\circ} \mathrm{C}$ and $12 \mathrm{~h}$ dark/light cycle) with standard laboratory diet and water ad libitum. The study was conducted after obtaining Institutional Animal Ethical Committee (IAEC) clearance (Proposal No: SVCP/IAEC/Ph.D/01/2014-15 dt 24.1.2015). 


\section{In vitro anti-inflammatory activities of MEIL}

\section{Cell culture and stimulation}

The murine monocytic macrophage cells RAW 264.7 was grown in a plastic culture flask in Dulbecco's Modified Eagle's Medium (DMEM) with L-glutamine supplemented with $10 \%$ fetal bovine serum (FBS) and $1 \%$ penicillin/streptomycin solution under $5 \% \mathrm{CO}_{2}$ at 37 ${ }^{\circ} \mathrm{C}$. After 4-5 days, cells were removed from the culture flask and centrifuged for $10 \mathrm{~min}$ at $1500 \mathrm{rpm}$. The medium was then removed and the cells re-suspended with fresh DMEM. The cell concentration was adjusted to $1.10^{6}$ cells $/ \mathrm{mL}$ in the same medium. $100 \mu \mathrm{L}$ of the above concentration were cultured in a 96-well plate for one day to become nearly confluent. Concentrations ranging from $10-100 \mu \mathrm{g} / \mathrm{mL}$ of the extract or standard (Aceclofenac) were prepared in DMEM to give a volume of $100 \mu \mathrm{L}$ in each well of a microtitre plate. Then wells were cultured with the vehicle, test extract and standard in the presence of $1 \mu \mathrm{g} / \mathrm{mL}$ of LPS for $24 \mathrm{~h}$.

\section{Nitric oxide inhibitory assay}

The nitrite concentration in the culture medium was measured as an indicator of NO production based on the Griess reaction (Hu et al., 2008). $100 \mu \mathrm{L}$ of each supernatant was mixed with the same volume of Griess reagent $(1 \%$ sulphanilamide in $5 \%$ phosphoric acid and $0.1 \%$ naphthylethylenediamine dihydrochlorie in water) and the remaining mixture was then incubated at room temperature for $10 \mathrm{~min}$. The absorbance at $540 \mathrm{~nm}$ was measured using a mictrotitre plate reader. Nitrite concentration in the supernatant was determined by comparison with a sodium nitrite standard curve.

\section{5-Lipoxygenase Inhibitory assay}

The 5-lipoxygenase inhibitory activity was used as an indicator of the anti-inflammatory activity. The assay was done using linoleic acid as substrate and 5-lipoxygenase as enzyme. A total volume of $200 \mu \mathrm{L}$ assay mixture containing $160 \mu \mathrm{L}$ sodium phosphate buffer $(100 \mathrm{mM}, \mathrm{pH} 8.0), 10 \mu \mathrm{L}$ test extract (10-100 $\mu \mathrm{g}$ in $100 \mathrm{mM}$ Tris buffer, $\mathrm{pH}$ 7.4) and $20 \mu \mathrm{L}$ of lipoxygenase enzyme was used. The contents were incubated at $25^{\circ} \mathrm{C}$ for $10 \mathrm{~min}$. The reaction was then initiated by the addition of $10 \mu \mathrm{L}$ linoleic acid solution. The change in absorbance was observed after $6 \mathrm{~min}$ at $234 \mathrm{~nm}$ (Komatou et al., 2010). All reactions were performed in triplicates in 96-well microplates. Aceclofenac was used as reference standard. The percentage inhibition was calculated by the following formula:

$$
\text { Inhibition }(\%)=\left[\mathrm{A}_{\text {Control }}-\mathrm{A}_{\text {Test }} / \mathrm{A}_{\text {Control }}\right] \times 100
$$

\section{Cyclooxygenase inhibitory assay}

In vitro COX-2 inhibitory activities of MEIL have been evaluated using ' $\mathrm{COX}$ (Ovine) inhibitor screening kit' (Cayman Chemical Company, Ann Arbor, MI) with 96-well plates. All the reagents added were prepared just before use. This screening assay directly measures $\mathrm{PGF}_{2} \alpha$ produced by $\mathrm{SnCl}_{2}$ reduction of $\mathrm{COX}$-derived $\mathrm{PGH}_{2}$. COX-1 and COX-2 initial activity tubes were prepared taking $950 \mu \mathrm{L}$ of reaction buffer, $10 \mu \mathrm{L}$ of heme and $10 \mu \mathrm{L}$ of COX-1 and COX-2 enzymes in respective tubes. Similarly, COX-1 and COX-2 inhibitor tubes were prepared by adding $20 \mu \mathrm{L}$ of the extract at various concentrations $(10-100 \mu \mathrm{g} / \mathrm{mL})$ in each tube in addition to the above ingredients. The background tubes corresponding to inactivated COX-1 and COX-2 enzymes obtained after keeping the tubes containing enzymes in boiling water for $3 \mathrm{~min}$ along with vehicle control. Reactions were initiated by adding $10 \mu \mathrm{L}$ of arachidonic acid in each tube and quenched with $50 \mu \mathrm{L}$ of $1 \mathrm{M} \mathrm{HCl}$. $\mathrm{PGH}_{2}$ thus formed was reduced to $\mathrm{PGF}_{2} \alpha$ by adding $100 \mu \mathrm{L}$ of $\mathrm{SnCl}_{2}$. The prostaglandin produced in each well was quantified using prostaglandin specific antiserum that binds with major prostaglandins and reading the plate at $405 \mathrm{~nm}$.

\section{In vivo anti-inflammatory activities of MEIL}

\section{Carrageenan-induced rat paw edema}

The rats were divided into four groups $(\mathrm{n}=6)$ and were treated orally with MEIL (200 \& $400 \mathrm{mg} / \mathrm{kg})$, aceclofenac $(10 \mathrm{mg} / \mathrm{kg})$, and vehicle control (0.3\% CMC, $1 \mathrm{~mL} / \mathrm{kg} /$ p.o. $)$. The administration of extract and standard drug was $1 \mathrm{~h}$ prior to injection of $0.1 \mathrm{ml}$ of $1 \%$ freshly prepared suspension of carrageenan in normal saline in the right hind paw sub plantar of each rat. The paw volume was measured initially and then at 1,3 and $5 \mathrm{~h}$ after the carrageenan injection by using plethysmometer (Sulaiman et al., 2010). The anti-inflammatory effect of MEIL was calculated by the following formula:

$$
\text { Anti-inflammatory activity }(\%)=(1-\mathrm{V} t / \mathrm{V} c) \times 100
$$

where $\mathrm{V} t$ represents the paw volume in drug treated animals and $\mathrm{V} c$ represents the paw volume of control groups animals.

\section{Cotton pellet granuloma method}

The animals were divided into four groups of six animals in each group. The rats were anaesthetized and sterile cotton pellets weighing $10 \pm 1 \mathrm{mg}$ were implanted subcutaneously into both sides of the groin region of 
each rat. Group I served as control and received the vehicle (0.3\% CMC, $1 \mathrm{~mL} / \mathrm{kg} / \mathrm{p}$. .o.). Group II animals received aceclofenac at a dose of $10 \mathrm{mg} / \mathrm{kg}$ for the same period. MEIL at the concentration of $200 \& 400 \mathrm{mg} / \mathrm{kg}$ was administered orally to groups III and IV animals for seven consecutive days from the day of cotton pellet implantation. On $8^{\text {th }}$ day the animals were killed by giving excess anesthesia and the pellets together with the granuloma tissues were carefully removed and made free from extraneous tissues. The wet pellets were weighed initially and then dried in an oven at $60{ }^{\circ} \mathrm{C}$ for $24 \mathrm{~h}$ to constant weight and were weighed again. Increment in the dry weight of the pellets was taken as a measure of granuloma formation. The antiproliferative effect of MEIL was compared with control (Jothimanivannan et al., 2010).

\section{In vivo antinociceptive activity of MEIL}

\section{Acetic acid induced writhing test}

The writhes were induced by intraperitoneal injection of $0.6 \%(\mathrm{v} / \mathrm{v})$ acetic acid $(80 \mathrm{mg} / \mathrm{kg})$. Group I served as control $(0.3 \% \mathrm{CMC}, 1 \mathrm{~mL} / \mathrm{kg} / \mathrm{p}$.o. $)$ and group II animals received aspirin at a dose of $300 \mathrm{mg} / \mathrm{kg}$. Two different doses of MEIL ( $200 \& 400 \mathrm{mg} / \mathrm{kg}$ ) were administered orally to the group III and group IV animals. The extract and standard drug were administered 30 min before chemical stimulus. The number of muscular contractions was counted over a period of $20 \mathrm{~min}$ and is expressed as writhing numbers (Purnima et al., 2009).

\section{Hot plate method}

the hot plate method in rats was performed by using Eddy's hot plate method. The evaluated parameters were the latency time for paw licking and jumping responses on exposure to the hot plate surface, kept at $55 \pm 1^{\circ} \mathrm{C}$. The animal was kept in the hot plate until it lifted one of its hind paws. For this method, the animals were divided into four groups of six animals each. Group I served as control (0.3\% CMC, $1 \mathrm{~mL} / \mathrm{kg} / \mathrm{p}$.o.). Group II received pentazocin at a dose of $5 \mathrm{mg} / \mathrm{kg}$. Group III and IV received MEIL at a dose of $200 \& 400 \mathrm{mg} / \mathrm{kg} /$ p.o. respectively. All the treatments were given $30 \mathrm{~min}$ before the thermal stimulus and the response was determined at 60,120 and $180 \mathrm{~min}$ (Nikajoo, 2009).

\section{Statistical analysis}

All values were expressed as mean \pm SEM. Statistical analysis was performed with one way analysis of variance (ANOVA) followed by Tukey Kramer Multiple Comparison test. $\mathrm{P}$ values $<0.05$ were considered to be statistically significant when compared to control.
Determination of $\mathrm{IC}_{50}$ values and statistical analysis were done by using GraphPad Prism v5.01 software.

\section{RESULTS AND DISCUSSION}

Inflammation is a reaction occurring in several types of tissue injuries, infections or immunological stimulation as a defense against foreign or altered endogenous substances. The process of inflammation comprises of a series of changes of the terminal tissues, which tend to eliminate the injurious agents and to repair the damaged tissue. Nitric oxide is a short-lived free radical produced from L-arginine by nitric oxide synthase (NOS) that mediates diverse functions by activating on various cells through interactions with different molecular targets. Although nitric oxide acts as an essential multifunctional mediator in various biological systems, excessive production of nitric oxide by inducible nitric oxide synthase (iNOS) is involved in various types of inflammation and multistage carcinogenesis at inflammatory sites (Lee et al., 2009; Wang et al., 2013). In the present study, a dose dependent and gradual increase in the percentage inhibition was observed with MEIL. Higher percentage inhibition (95.7) was observed at $100 \mu \mathrm{g} / \mathrm{mL}$ concentration of MEIL. The $\mathrm{IC}_{50}$ value was found to be $60.67 \mu \mathrm{g} / \mathrm{mL}$ for MEIL. Aceclofenac at a concentration range of $10-100 \mu \mathrm{g} / \mathrm{mL}$ was employed and served as reference standard. The lowest dose $(10 \mu \mathrm{g} / \mathrm{mL})$ produced an inhibitory percentage of 20.1 and the highest concentration produced $97.03 \%$ inhibition. Like MEIL, a dose dependent increase in the percentage of inhibition was observed in all the concentrations tested. The $\mathrm{IC}_{50}$ value of aceclofenac against nitric oxide inhibitory assay was found to be $79.43 \mu \mathrm{g} / \mathrm{mL}$. The results reveal that the extract inhibits the production of nitric oxide as stimulated by LPS in mouse macrophage cell line RAW 264.7. The results obtained are presented in Table I.

Lipoxygenases (LOX) are members of a class of non-heme iron-containing dioxygenases that catalyze the addition of molecular oxygen to fatty acids containing a cis, cis-1,4-pentadiene system to give an unsaturated fatty acid hydroperoxides. It has been proved that these LOX products play a key role in variety of disorders such as bronchial asthma, inflammation and tumor angiogenesis. In human tissues, LOX is expressed in platelet, eosinophils, neutrophils, colonic tissues, lung tissues and bone marrow cells. Neutrophils contain 5-LOX which converts the arachidonic acid to 5-hydroxy-6,8,11,14-eicosatetraenoic acid (5-HPETE). This 5-HPETE is converted into a series of leukotrienes and the nature of the final product varies according to the tissue. Leukotrienes are mediators of 
allergic response and inflammation. Inhibitors of 5-LOX are used in the treatment of inflammation (Shah et al., 2013). Various concentrations (10-100 $\mu \mathrm{g} / \mathrm{mL})$ of MEIL were analyzed for 5-lipoxygenase inhibitory activity. A proportionate increase in the percentage of lipoxygenase was observed for MEIL. The $\mathrm{IC}_{50}$ value of MEIL was found to be $59.99 \mu \mathrm{g} / \mathrm{mL}$. Maximum inhibition (97.6\%) by MEIL was observed at the concentration of $100 \mu \mathrm{g} / \mathrm{mL}$. Aceclofenac at the concentration of $100 \mu \mathrm{g} / \mathrm{mL}$ exhibits a percentage inhibition of 97.8 and the $\mathrm{IC}_{50}$ value was found to be $45.97 \mu \mathrm{g} / \mathrm{mL}$. A gradual increase in percentage of inhibition was observed for increasing concentration of aceclofenac. However the concentration of MEIL required for inhibiting lipoxygenase enzyme was higher than that of the standard drug aceclofenac. The methanolic extract of I. linnaei inhibits 5-LOX in concentration dependent manner and this inhibitory activity might be attributed to the anti-inflammatory potential of the extract. The results are presented in Table I.

The enzyme cyclooxygenase (COX) has been played as a key role in inflammatory process. It is a membrane bound glycoprotein found in the endoplasmic reticulum of prostanoid forming cells. It occurs catalytically in two active forms i.e. COX-1 and COX-2. These two isoforms of $\mathrm{COX}$ are almost identical in structure but have important differences in substrate and inhibitor selectivity and in their intracellular locations (Gacche et al., 2011). Among these two isoforms, COX-2 involved in mediating the inflammatory process produces $\mathrm{PGE}_{2}$ from endogenous arachidonic acid. COX-2 is inducible and dramatically up-regulated by a variety of stimuli such as cytokines, mitogens, oncogenes, growth factor and tumor promoters and is detectable in only certain type of tissues. Non-steroidal anti-inflammatory drugs (NSAIDs) are COX inhibitors and they also inhibit COX-1. This is problematic because COX-1 is essential for the repair and maintenance of stomach linings, which result in varying degrees of gastric ulcerations, perforation or obstructions (Gately, 2000). So there is a need for agents which inhibit COX-2 selectively without affecting COX-1. In the present study, the methanolic extract of I. linnaei was screened for its inhibitory efficacy against COX-1 and COX-2.

The in vitro cyclooxygenase inhibitory study demonstrated that the plant extract had good and selective inhibitory activity against COX-2 as compared to COX1. The results obtained revealed that MEIL selectively inhibited COX-2 catalysed prostaglandin biosynthesis with an $\mathrm{IC}_{50}$ value of $15.82 \mu \mathrm{g} / \mathrm{mL}$, compared with COX1 derived prostaglandin synthesis which showed an $\mathrm{IC}_{50}$ value of $76.48 \mu \mathrm{g} / \mathrm{mL}$. The resulting COX-2 selectivity was 4.83 (Table II). A comparison was also made with COX-1/COX-2 selectivity ratio of some traditional NSAIDs (Indomethacin and aceclofenac) and Celecoxib, a synthetic selective COX-2 inhibitor, obtained in the same assay system. Indomethacin and aceclofenac non-selectively inhibited COX $-1 / 2$ ratio. The percentage inhibition produced by MEIL against COX-1 ranged between 12.6 and 65.4, whereas it was 30.17 to 94.47 for COX-2. Maximum enzyme inhibitory effect was observed at $100 \mu \mathrm{g} / \mathrm{mL}$ for both COX-1 and COX-2. The extract inhibits both isoforms

TABLE I - Nitric oxide and 5-lipoxygenase Inhibitory activity of MEIL

\begin{tabular}{|c|c|c|c|c|c|}
\hline \multirow[b]{2}{*}{ Sample } & \multirow{2}{*}{$\begin{array}{c}\text { Concentration } \\
(\mu \mathrm{g} / \mathrm{mL})\end{array}$} & \multicolumn{2}{|c|}{ NO Inhibitory Activity } & \multicolumn{2}{|c|}{ 5-lipoxygenase Inhibitory Activity } \\
\hline & & $\begin{array}{c}\text { Enzyme Inhibition } \\
(\%)\end{array}$ & $\begin{array}{c}\mathrm{IC}_{50} \\
(\mu \mathrm{g} / \mathrm{mL})\end{array}$ & $\begin{array}{c}\text { Enzyme Inhibition } \\
(\%)\end{array}$ & $\begin{array}{c}\mathrm{IC}_{50} \\
(\mu \mathrm{g} / \mathrm{mL})\end{array}$ \\
\hline \multirow{6}{*}{ MEIL } & 10 & $20.73 \pm 0.75$ & \multirow{6}{*}{60.67} & $19.9 \pm 0.96$ & \multirow{6}{*}{59.99} \\
\hline & 20 & $26.3 \pm 0.9$ & & $24.8 \pm 1.16$ & \\
\hline & 40 & $36.83 \pm 1.57$ & & $39.27 \pm 1.7$ & \\
\hline & 60 & $54.87 \pm 3.48$ & & $61.87 \pm 1.36$ & \\
\hline & 80 & $77.7 \pm 2.14$ & & $91.87 \pm 2.62$ & \\
\hline & 100 & $95.7 \pm 1.55$ & & $97.6 \pm 1.76$ & \\
\hline \multirow{6}{*}{ Aceclofenac } & 10 & $20.1 \pm 1.38$ & \multirow{6}{*}{79.43} & $21 \pm 1.13$ & \multirow{6}{*}{45.97} \\
\hline & 20 & $24.56 \pm 4.15$ & & $32.4 \pm 1.53$ & \\
\hline & 40 & $37.9 \pm 2.23$ & & $49.83 \pm 1.45$ & \\
\hline & 60 & $60.93 \pm 2.04$ & & $73.4 \pm 1.69$ & \\
\hline & 80 & $84.15 \pm 1.49$ & & $92.36 \pm 2.75$ & \\
\hline & 100 & $97.03 \pm 1.43$ & & $97.8 \pm 1.6$ & \\
\hline
\end{tabular}

Data were expressed as Mean \pm SD $(n=3)$; Average of three independent determinations. 
of cyclooxygenase in concentration dependent manner. At the same time, COX-2 selectivity ratio is more than the standard NSAIDs such as indomethacin and aceclofenac. The results obtained indicate that the extract is having selective COX-2 inhibition.

In the present study, the anti-inflammatory and anti-nociceptive activities of the methanolic extract of Indigofera linnaei (MEIL) has been established in both acute and chronic inflammation models as employed. Carrageenan induced rat paw edema is a suitable test for evaluating anti-inflammatory drugs which has been used to assess the anti-edematous effect of natural products (Panthong et al., 2003). The development of edema in the paw of the rat after injection of carrageenan is believed to be biphasic event. The initial phase observed during the first hour is attributed to the release of histamine and serotonin; the second phase is due to the release of prostaglandin, protease and lysosome (Paviaya et al., 2013). Based on this, it could be hypothesized that the suppression of the first phase may be due to inhibition of the release of early mediators, such as histamine and serotonin, and the action in the second phase may be explained by an inhibition of cyclooxygenase (Gobianand et al., 2010). Previous studies suggest that the injection of carrageenan into the rat paw induces the liberation of bradykinin, which later induces the biosynthesis of prostaglandins and other autocoids, which are responsible for the formation of the inflammatory exudates. Besides, in the carrageenan induced rat paw edema model, the production of prostanoids has been through the serum expression of COX-2 by a positive feedback mechanism (Ueno et al., 2000).

Sub-plantar injection of carrageenan in rats showed to a time-dependent increase in paw volume (Table III), which was observed at $1 \mathrm{~h}$ and maximum swelling at $5 \mathrm{~h}$ after administration of carrageenan injection in the control group. However, carrageenan induced inflammation was significantly $(\mathrm{p}<0.001)$ reduced in all phases of the experiment by the treatment with MEIL 200 and $400 \mathrm{mg} / \mathrm{kg}$, as well as aceclofenac. No significant difference in reduction was observed by MEIL when compared to the standard drug aceclofenac, which indicates the equipotent nature of the extract. Maximum inhibition was observed at the dose of $400 \mathrm{mg} / \mathrm{kg}$. The results reveal that the methanol extract of I. linnaei had a significant anti-inflammatory effect on the tested dose levels. The extract at a dose of $400 \mathrm{mg} / \mathrm{kg}$, had higher anti-inflammatory potential than aceclofenac (NSAID), a cyclooxygenase inhibitor, while at the dose of $200 \mathrm{mg} / \mathrm{kg}$ the activity was similar to that of aceclofenac. Therefore, the results obtained suggest that the mechanism of action of MEIL may be related to the inhibition of prostaglandin biosynthesis.

The cotton pellet granuloma method has been widely employed to assess the transductive, exudative

TABLE II - Comparison of $\mathrm{IC}_{50}$ values of various COX inhibitors with MEIL

\begin{tabular}{lccc}
\hline Sample/Drugs & \multicolumn{2}{c}{$\mathbf{I C}_{\mathbf{5 0}}(\boldsymbol{\mu g} / \mathbf{m L})$} & $\begin{array}{c}\text { COX-2 Selectivity } \\
\text { (COX-1/COX-2)* }\end{array}$ \\
\cline { 2 - 4 } & COX-1 & COX-2 & 4.83 \\
MEIL & 76.48 & 15.82 & 50.33 \\
Celecoxib & 24.16 & 0.48 & 0.015 \\
Indomethacin & 0.006 & 0.38 & 0.3 \\
Aceclofenac & 0.08 & 0.26 & \\
\hline
\end{tabular}

* Ratio of the $\mathrm{IC}_{50}$ values for COX-1 and COX-2 can be used as an indication of the COX-2 selectivity of inhibitors. A COX-1/ COX-2 ratio of more than 1 indicates preferential COX-2 selectivity.

TABLE III - Effect of MEIL on Carrageenan Induced Paw Edema in Rats

\begin{tabular}{lcccc}
\hline \multirow{2}{*}{ Design of Treatment } & \multirow{2}{*}{ Dose $(\mathbf{m g} / \mathbf{k g})$} & \multicolumn{3}{c}{ Paw Volume $(\mathbf{m L})$} \\
\cline { 3 - 5 } & & $\mathbf{1 ~ h}$ & $\mathbf{3} \mathbf{~ h}$ & $\mathbf{5} \mathbf{~ h}$ \\
\hline Control & - & $0.37 \pm 0.01$ & $0.52 \pm 0.03$ & $0.95 \pm 0.03$ \\
Aceclofenac & 10 & $0.24 \pm 0.01(35.13)$ & $0.30 \pm 0.02^{\mathrm{a}}(42.3)$ & $0.28 \pm 0.01^{\mathrm{a}}(70.52)$ \\
MEIL & 200 & $0.27 \pm 0.01(27.02)$ & $0.35 \pm 0.01^{\mathrm{a}}(32.69)$ & $0.31 \pm 0.02^{\mathrm{a}}(67.37)$ \\
MEIL & 400 & $0.26 \pm 0.012(29.73)$ & $0.31 \pm 0.02^{\mathrm{a}}(40.38)$ & $0.25 \pm 0.06^{\mathrm{a}}(73.68)$ \\
\hline
\end{tabular}

$\mathrm{n}=6$; Data were expressed as Mean \pm SEM; ${ }^{\mathrm{a}} \mathrm{p}<0.001$ vs Control; Data were analyzed by One way ANOVA followed by Tukey Kramer Multiple Comparison test. Percentage inhibition is given in parenthesis. 
and proliferative components of chronic inflammation is a typical feature of established chronic inflammatory reaction. The fluid absorbed by the pellet greatly influences the wet weight of the granuloma and dry weight correlates well with the granuloma of the granulomatous tissue formed (Joseph et al., 2010). In the present investigation, the methanol extract of I. linnaei registered profound anti-inflammatory activity against cotton pellet granuloma in rats (Table IV). The extract exhibited a significant $(\mathrm{p}<0.001)$ anti-inflammatory activity and the results were comparable with that of standard drug aceclofenac. The extract at the dose of $400 \mathrm{mg} / \mathrm{kg}$ showed the maximum granuloma inhibition, which is equal to aceclofenac.

In the writhing test, high levels of prostaglandins PGE2 $\alpha$ and PGF $2 \alpha$ was observed during the first $30 \mathrm{~min}$ after acetic acid injection. Nevertheless, it was found that the intraperitoneal administration of acetic acid induces not only the liberation of prostaglandins, but also of the release of pro-inflammatory cytokines, such as tumor necrosis factor-a (TNF- $\alpha$ ), interleukine-1b (IL-1b) and IL-8 from resident peritoneal macrophages and mast cells (Mothana, 2011). The oral administration of MEIL induced the analgesic activity significantly and the results are presented in Table $\mathrm{V}$. The treatment of animals with MEIL at the dose of 200 and $400 \mathrm{mg} / \mathrm{kg}$, produced a significant $(\mathrm{p}<0.001)$ and dose dependent inhibition in abdominal writhes produced by acetic acid. The inhibition by MEIL at the dose of $400 \mathrm{mg} / \mathrm{kg}$ was nearly similar to that produced by the standard drug aspirin. Thus, the results obtained for the writhing test using acetic acid are similar to those obtained for the edematogenic test using carrageenan, since MEIL effectively inhibited the writhings in mice in dose dependent manner. The results were comparable with the group treated with standard drug aspirin, which indicate that the antinociceptive effect of I. linnaei might be attributed to the inhibition of the synthesis of some pro-inflammatory mediators such as prostaglandins and cytokines.

The hot plate test is a classical approach widely applied in the analgesic investigations for several decades. The hot plate test when associated with the writhing test, can usually distinguish central from peripheral effects (Srinivasan et al., 2003). Some analgesic drugs such as aspirin usually have few effects in the hot plate test indicating their peripheral analgesic activities. But some other analgesic drugs such as ibuprofen and morphine can decrease prostaglandin synthesis via central inhibition of cyclooxygenase (Zhu et al., 2011) or bind to specific opioid receptors in the central nervous system, exhibiting both their peripheral and central analgesic activities. However, the hot plate test was undertaken to verify if MEIL would have any central analgesic effect and the results are presented in Table VI. In this analgesic testing model, pentazocine at a dose of $5 \mathrm{mg} / \mathrm{kg}$, significantly prolonged the reaction time of animals with relatively extended duration of

TABLE IV - Effect of MEIL on Cotton Pellet Granuloma in Rats

\begin{tabular}{lccccc}
\hline $\begin{array}{l}\text { Design of } \\
\text { Treatment }\end{array}$ & Dose (mg/kg) & Wet weight (mg) & Inhibition (\%) & Dry weight (mg) & Inhibition (\%) \\
\hline Control & - & $203.8 \pm 6.24$ & - & $56.17 \pm 2.17$ & - \\
Aceclofenac & 10 & $63.17 \pm 2.19^{\mathrm{a}}$ & 69 & $25.5 \pm 2.08^{\mathrm{a}}$ & 54.6 \\
MEIL & 200 & $69.67 \pm 2.67^{\mathrm{a}}$ & 65.81 & $28.8 \pm 2.13^{\mathrm{a}, \mathrm{b}}$ & 48.72 \\
MEIL & 400 & $58.47 \pm 1.88^{\mathrm{a}}$ & 71.31 & $24.3 \pm 1.75^{\mathrm{a}}$ & 56.73 \\
\hline
\end{tabular}

$\mathrm{n}=6$; Data were expressed as Mean $\pm \mathrm{SEM} ;{ }^{\mathrm{a}} \mathrm{p}<0.001 v s$ Control; ${ }^{\mathrm{b}} \mathrm{p}<0.01 v s$ Aceclofenac; Data were analyzed by One way ANOVA followed by Tukey Kramer Multiple Comparison test.

TABLE V - Effect of MEILon Chemical Stimulus Induced Pain in Mice

\begin{tabular}{lccc}
\hline Design of Treatment & Dose (mg/kg) & No. ofwrithings & Inhibition (\%) \\
\hline Control & - & $105.66 \pm 3.20$ & - \\
Aspirin & 300 & $49.67 \pm 2.99^{\mathrm{a}}$ & 53 \\
MEIL & 200 & $66.83 \pm 2.23^{\mathrm{a}, \mathrm{b}}$ & 36.75 \\
MEIL & 400 & $50 \pm 2.15^{\mathrm{a}}$ & 52.68 \\
\hline
\end{tabular}

$\mathrm{n}=6$; Data were expressed as Mean \pm SEM; ${ }^{a} \mathrm{p}<0.001 v s$ Control; ${ }^{\mathrm{b}} \mathrm{p}<0.001 v s$ Aspirin; Data were analyzed by One way ANOVA followed by Tukey Kramer Multiple Comparison test. 
TABLE VI - Effect of methanolic extract of Indigofera linnae on Thermal Stimulus Induced Pain in Mice

\begin{tabular}{lccccc}
\hline \multirow{2}{*}{$\begin{array}{l}\text { Design of } \\
\text { Treatment }\end{array}$} & \multirow{2}{*}{ Dose (mg/kg) } & \multicolumn{4}{c}{ Reaction Time (Sec.) } \\
\cline { 2 - 5 } & & $\mathbf{0 ~ h}$ & $\mathbf{1 ~ h}$ & $\mathbf{2 ~ h}$ & $\mathbf{3 ~ h}$ \\
\hline Control & - & $2.53 \pm 0.14$ & $2.45 \pm 0.08$ & $2.53 \pm 0.1$ & $2.58 \pm 0.09$ \\
Pentazocine & 5 & $2.4 \pm 0.13$ & $7.41 \pm 0.35^{\mathrm{a}}$ & $9.95 \pm 0.41^{\mathrm{a}}$ & $8.38 \pm 0.25^{\mathrm{a}}$ \\
MEIL & 200 & $2.5 \pm 0.13$ & $3.21 \pm 0.28^{\mathrm{b}}$ & $3.12 \pm 0.15^{\mathrm{b}}$ & $2.71 \pm 0.18^{\mathrm{b}}$ \\
MEIL & 400 & $2.5 \pm 0.14$ & $3.28 \pm 0.18^{\mathrm{b}}$ & $3.02 \pm 0.2^{\mathrm{b}}$ & $2.88 \pm 0.31^{\mathrm{b}}$ \\
\hline
\end{tabular}

$\mathrm{n}=6$; Data were expressed as Mean $\pm \mathrm{SEM} ;{ }^{\mathrm{a}} \mathrm{p}<0.001 v s$ Control; ${ }^{\mathrm{b}} \mathrm{p}<0.001$ vs Pentazocine; Data were analyzed by One way ANOVA followed by Tukey Kramer Multiple Comparison test.

stimulation, confirming centrally mediated activity. The results obtained from the extract treated groups revealed no significant activity when compared to control group and a highly significant difference was observed with the group treated with pentazocin $(5 \mathrm{mg} / \mathrm{kg})$. Hence, it is assumed that MEIL has no significant analgesic effect on the central nervous system.

Recently our biological studies on methanol extract of I.linnaei reported potent antioxidant and free radical scavenging activities as well as a good anticancer activity (Kumar et al., 2011a; Kumar et al., 2011b). Many Indigofera species such as I. colutea, I. macrocalyx, I. nigritiana, I. puchra, I. tinctoria, I. trita and I. cassioides exhibited potent anti-inflammatory, analgesic and lipoxygenase inhibitory activities (Bakaso et al., 2013; Kumar et al., 2009; Kumar et al., 2013). Reports of the previous studies and the traditional use of this medicinal plant encouraged us to extend our evaluation using several in vitro and in vivo models of inflammation and nociception in rodent models. It is important to point out that this work represents the first report on the antiinflammatory and antinociceptive activities of I. linnaei.

Reactive Oxygen Species (ROS) and Reactive Nitrogen Species (RNS) participate in normal cell function as well as in pathological disorders such as inflammation. Several studies have demonstrated the participation of ROS and RNS in inflammation models. Preliminary phytochemical and quantitative analysis of MEIL indicated the presence of rich amount of flavonoids and phenolic compounds in MEIL (Kumar et al., 2011a). Anti-inflammatory and antinociceptive activities as well as antioxidant potential of many plants have been attributed to their flavonoids (Garcia-Mediavilla et al., 2007; Gonzalez et al., 2011; Sharififar et al., 2009) or to their high triterpene (Ammon, 2006; Mothana et al., 2011). Flavonoids are known as important secondary plant products in many medicinal plants. They have attracted much attention in relation to their wide range of activities in the prevention of cancer, inflammation and coronary heart disorders (Garcia-Mediavilla et al., 2007). Previous reports suggest that these compounds may inhibit several enzymes, which are activated in certain inflammatory conditions. Prostaglandins and nitric oxide (NO) biosynthesis is involved in inflammation. Moreover, inducible nitric oxide synthase (iNOS), cyclooxygenase (COX-2) and lipooxygenase are responsible for the production of large amounts of these pro-inflammatory mediators (Garcia-Mediavilla et al., 2007). Different studies confirm that flavonoids like quercetin and kaempferol significantly decrease the levels of iNOS, COX-2, lipoxygenase and reactive C-protein (RCP) in a concentration dependent manner (Morales et al., 2006; Tunon et al., 2009). Furthermore, some investigated flavonoids such as kaempferol, quercetin and daidzein also inhibit the activation of the signal transducer and activator of transcription 1 (STAT-1), another important transcription factor for iNOS. Luteolin 7-glucoside, kaempferol and quercetin effectively inhibit lipopolysaccharide (LPS)-induced $\mathrm{PGE}_{2}$ production. Four flavonoids significantly inhibit LPS-induced COX-2 expression, while mPGES-1 expression was downregulated by kaempferol and isorhamnetin (Hamalainen et al., 2011). The observed beneficial effects of methanol extract of I. linnaei on inflammatory and nociceptive responses in rodents may be due to the presence of these phytochemicals.

\section{CONCLUSION}

All the data obtained in the present work demonstrate the possible development of methanol extract of Indigofera linnaei as a novel and potential drug in the management of inflammation and pain, which are probably mediated via inhibition of various autacoids formation and release. Further detailed investigation is underway to determine the exact phytoconstituents that are responsible for these activities. 


\section{ACKNOWLEDGEMENT}

We thank the Management and Principal of Swamy Vivekanandha College of Pharmacy, for rendering support to carry out this work. We have no financial or personal conflictsof interest related to this work.

\section{REFERENCES}

AMIRA, S.; DADE, M.; SCHINELLA, G.; JOSE-LUIS, R. Anti-inflammatory, anti-oxidant and apoptotic activities of four plant species used in folk medicine in the Mediterranean basin. Pak. J. Pharm. Sci., v.25, n.1, p.65-72, 2012.

AMMON, H.P. Boswellic acids in chronic inflammatory diseases. Planta. Med., v.72, n.12, p.1100-1116, 2006.

BAKASSO, S.; LAMIEN-MEDA, A.; LAMIEN, C.E.; KIENDERBEOGO, M.; COULIBALY, A.Y.; COMPAORE, M.; MEDA, N.R.; NACOULMA, O.G. In vitro inhibition of acetylcholinesterase, lipoxygenase, xanthine oxidase and antibacterial activities of five Indigofera (Fabaceae) aqueous acetone extracts from Burkina Faso. Curr. Res. J. Biol. Sci., v.5, n.3, p.115-122, 2013.

BEPARY, S.; BIPLAB, K.D.; SITESH, C.B.; JOYDEV, K.K.; ABU, S.S.R.; BIDYUT, K.D. Anti-inflammatory activity of indanyltetrazole derivatives. Pak. J. Pharm. Sci., v.21, n.3, p.295-298, 2008.

DHARMASIRI, M.G.; JAYAKODY, J.R.A.C.; GALHENA, G.; LIYANAGE, S.S.P.; RATNASOORIYA, W.D. Antiinflammatory and analgesic activities of mature fresh leaves of Vitex negundo. J. Ethnopharmacol., v.87, n.2/3, p.199-206, 2003.

GACCHE, R.; SHAIKH, R.; PUND, M.; DESHMUKH, R. Cyclooxygenase inhibitory, cytotoxicity and free radical scavenging activities of selected medicinal plants used in Indian traditional medicine. Phcog. J., v.3, n.19, p.57-64, 2011.

GARCIA-MEDIAVILLA, V.; CRESPO, I.; COLLADO, P.S.; ESTELLER, A.; SANCHEZ-CAMPOS, S.; TUNON, M.J.; GONZALEZ-GALLEGO, J. The anti-inflammatory flavones quercetin and kaempferol cause inhibition of inducible nitric oxide synthase, cyclooxygenase- 2 and reactive C-protein, and down regulation of the nuclear factor кB pathway in Chang Liver cells. Eur. J. Pharmacol., v.557, n.2/3, p.221-229, 2007.
GATELY, S. The contributions of cyclooxygenase-2 to tumor angiogenesis. Cancer Metastasis Rev., v.19, n.1/2, p.19-27, 2000.

GOBIANAND, K.; VIVEKANANDAN, P.; PRADEEP, K.; MOHAN, C.V.R.; KARTHIKEYAN, S. Anti-inflammatory and antipyretic activities of Indian medicinal plant Cassia fistula Linn. (Golden Shower) in Wistar albino rats. Int. J. Pharmacol., v.6, n.6, p.719-725, 2010.

GONZALEZ, R.; BALLESTER, I.; LOPEZ-POSADAS, R.; SUAREZ, M.D.; ZARZUELO, A.; MARTINEZAUGUSTIN, O.; DE MEDINA, F. Effects of flavonoids and other polyphenols on inflammation. Crit. Rev. Food Sci. Nutr., v.51, n.4, p.331-362, 2011.

HAMALAINEN, M.; NIEMINEN, R.; ASMAWI, M.Z.; VUORELA, P.; VAPAATALO, H.; MOILANEN, E. Effects of flavonoids on prostaglandin $\mathrm{E} 2$ production and on $\mathrm{COX}$ 2 and mPGES-1 expressions in activated macrophages. Planta Med., v.77, n.13, p.1504-1511, 2011.

HEMALATHA, S.; SUBRAMANIAN, N.; RAVICHANDRAN, V.; CHINNASWAMY, K. Wound healing activity of Indigofera enneaphylla Linn. Indian J. Pharm. Sci., v.63, n.4, p.331-333, 2001.

HU, X.; JIN, H.; XU, W.; ZHANG, W.; LIU, X.; YAN, S.; CHEN, M.; LI, J.; ZHANG, W. Anti-inflammatory and analgesic effect of Daphne retusa Hemsl. J. Ethnopharmacol., v.120, n.1, p.118-122, 2008.

JOSEPH, J.M.; SOWNDHARARAJAN, K.; MANIAN, S. Evaluation of analgesic and anti-inflammatory potential of Hedyotis puberula (G. Don) R. Br. ex Arn. in experimental animal models. Food Chem. Toxicol., v.48, n.7, p.18761880, 2010.

JOTHIMANIVANNAN, C.; KUMAR, R.S.; SUBRAMANIAN, $\mathrm{N}$. Anti-inflammatory and analgesic activities of ethanol extract of aerial parts of Justicia gendarussa Burm. Int. J. Pharmacol., v.6, n.3, p.278-283, 2010.

KOMATOU, G.P.P.; VILJOEN, A.M.; STEENKAMP, P. Antioxidant, anti-inflammatory activities and HPLC analysis of South African Salvia species. Food Chem., v.119, n.2, p.684-688, 2010.

KUMAR, R.; RAJKAPOOR, B.; PERUMAL, P. Antitumor and cytotoxic activities of methanol extract of Indigofera linnaei Ali. Asian Pac. J. Cancer Prev., v.12, n.3, p.613-618, 2011 b. 
KUMAR, R.S.; RAJKAPOOR, B.; PERUMAL, P. Antiinflammatory and analgesic activities of ethanol extract of Indigofera trita Linn. PharmacologyOnline, v.1, p.278-289, 2009.

KUMAR, R.S.; RAJKAPOOR, B.; PERUMAL, P. Antiinflammatory and anti-nociceptive activities of methanolic leaf extract of Indigofera cassioides Rottl. Ex. DC. J. Acute Dis., v.2, n.4, p.322-326, 2013.

KUMAR, R.S.; RAJKAPOOR, B.; PERUMAL, P. Antioxidant potential of Indigofera linnaei Ali: an in vitro study. PharmacologyOnline, v.1, p.710-720, 2011a.

LEE, J.; KIM, K.A.; JEONG, S.; LEE, S.G.; PARK, H.J.; KIM, N.J.; LIM, S. Anti-inflammatory, anti-nociceptive, and antipsychiatric effects by the rhizomes of Alpinia officinarum on complete Freund's adjuvant induced arthritis in rats. $J$. Ethnopharmacol., v.126, n.2, p.258-264, 2009.

MAJAK, W.; BENN, M.; MCEWAN, D.; PASS, M.A. Three nitropropanoyl esters of glucose from Indigofera linnaei. Phytochemistry, v.31, n.7, p.2393-2395, 1992.

MORALES, A.I.; VICENTE-SANCHEZ, C.; JERKIC, M.; SANTIAGO, J.M.; SANCHEZ-GONZALEZ, P.D.; PEREZ-BARRIOCANAL, F.; LOPEZ-NOVOA, J.M. Effect of quercetin on metallothionein, nitric oxide synthase and cyclooxygenase-2 expression on experimental chronic cadmium nephrotoxicity in rats. Toxicol. Appl. Pharmacol., v.210, n.1/2, p.128-135, 2006.

MORO, C.; IRENE, P.; MIGUEL, L.; MATILDE, D.A.; EVA, G.; ANA, V.; JOSE, A.M.; GARCIA-LAFUENTE, A. Antiinflammatory activity of methanolic extracts from edible mushrooms in LPS activated RAW 264.7 macrophages. Food Chem., v.130, n.2, p.350-355, 2012.

MOTHANA, R.A. Anti-inflammatory, antinociceptive and antioxidant actitivities of the endemic Soqotraen Boswellia elongata Balf. f. and Jatropha unicostata Balf. f. in different experimental models. Food Chem. Toxicol., v.49, n.10, p.2594-2599, 2011.

MOTHANA, R.A.A.; HASSON, S.S.; SCHULTZE, W.; MOWITZ, A.; LINDEQUIST, U. Phytochemical composition and in vitro antimicrobial and antioxidant activities of essential oils of three endemic Soqotraen Boswellia species. Food Chem., v.126, n.3, p.1149-1154, 2011 .
NIKAJOO, L.T. Analgesic activity of aqueous and alcohol root extracts of Pergularia daemia (forsk.) chiov. Int. J. Pharm. Pharm. Sci., v.1, suppl.1, p.33-37, 2009.

PANTHONG, A.; KANJANAPOTHI, D.; TAESOTIKUL, T.; WONGCOME, T.; REUTRAKUL, V. Anti-inflammatory and antipyretic properties of Clerodendrum petasites $\mathrm{S}$. Moore. J. Ethnopharmacol., v.85, n.1, p.151-156, 2003.

PAVIAYA, U.S.; KUMAR, P.; WANJARI, M.M.; THENMOZHI, S.; BALAKRISHNAN, B.R. Analgesic and anti-inflammatory activity of root bark of Grewia asiatica Linn. in rodents. Ancient Sci. Life., v.32, n.3, p.150-155, 2013.

P UR N IM A, A .; K O T I, B .C .; T I KA R E, V.P. ; VISWANATHASWAMY, A.; THIPPESWAMY, A.H.; DABADI, P. Evaluation of analgesic and antipyretic activities of Centratherum anthelminticum $(\mathrm{L})$ kuntze seed. Indian J. Pharm. Sci., v.71, n.4, p.461-464, 2009.

RAJENDRAPRASAD, Y.; CHAKRADHAR, V. A new isoflavone from Indigofera linnaei. Indian J. Chem., v.43B, n.8, p.1807-1808, 2004.

SHAH, S.M.A.; ASHRAF, M.; AHMED, I.; ARSHAND, S.; YAR, M.; LATIF, A. Anti-lipoxygenase activity of some indigenous medicinal plants. J. Med. Plants Res., v.7, n.6, p.219-222, 2013.

SHARIFIFAR, F.; DEHGHN-NUDEH, G.; MIRTAJALDINI, M. Major flavonoids with antioxidant activity from Teucrium polium L. Food Chem., v.112, n.4, p.885-888, 2009.

SRINIVASAN, K.; MURUGANANDAN, S.; LAL, J.; CHANDRA, S.; TANDAN, S.K.; RAVIPRAKASH, V.; KUMAR, D. Antinoniceptive and antipyretic activities of Pongamia pinnata leaves. Phytother. Res., v.17, n.3, p.259-264, 2003.

SULAIMAN, M.R.; PERIMAL, E.K.; AKHTAR, M.N.; MOHAMAD, A.S.; KHALID, M.H.; TASRIP, N.A.; MOKHTAR, F.; ZAKARIA, Z.A.; LAJIS, N.H.; ISRAF, D.A. Anti-inflammatory effect of zerumbone on acute and chronic inflammation models in mice. Fitoterpia, v.81, n.7, p.855-858, 2010. 
TUNON, M.J.; GARCIA-MEDIAVILLA, M.V.; SANCHEZCAMPOS, S.; GONZALEZ-GALLEGO, J. Potential of flavonoids as anti-inflammatory agents: modulation of pro-inflammatory gene expression and signal transduction pathways. Curr. Drug Metab., v.10, n.3, p.256-271, 2009.

UENO, A.; NARABA, H.; IKEDA, Y.; USHIKUBI, F.; MURATA, T.; NARUMIYA, S.; OH-ISHI, S. Intrinsic prostacyclin contributes to exudation induced by bradykinin or Carrageenan: a study on the paw edema-induced in IPreceptor- deficient mice. Life Sci., v.66, n.12, p.155-160, 2000.

VIJAYALAKSHMI, A.; RAVICHANDIRAN, V.; VELRAJ, M.; HEMALATHA, S.; SUDHARANI, G.; JAYAKUMARI, S. Anti-anaphylactic and anti-inflammatory activities of a bioactive alkaloid from the root bark of Plumeria acutifolia Poir. Asian Pac. J. Trop. Biomed., v.1, n.5, p.401-405, 2011.

WANG, B.S.; HUANG, G.J.; LU, Y.H.; CHANG, L.W. Antiinflammatory effects of an aqueous extract of Welsh onion green leaves in mice. Food Chem., v.138, n.2/3, p.751-756, 2013.
WEALTH of India: a dictionary of Indian raw materials and industrial products. New Delhi: CSIR, 1992. v.5, p.178-179.

YONATHAN, M.; ASRES, K.; ASSEFA, A.; BUCAR, F. In vivo anti-inflammatory and anti-nociceptive activities of Cheilanthes farinose. J. Ethnopharmacol., v.108, n.3, p.462-470, 2006.

ZHU, Z.Z.; MA, K.J.; RAN, X.; ZHANG, H.; ZHENG, C.J.; HAN, T.; ZHANG, Q.Y.; QIN, L.P. Analgesic, antiinflammatory and antipyretic activities of the petroleum ether fraction from the ethanol extract of Desmodium podocarpum. J. Ethnopharmacol., v.133, n.3, p.1126-1131, 2011.

Received for publication on $8^{\text {th }}$ August 2015 Accepted for publication on $27^{\text {th }}$ October 2015 
